\title{
UPAYA MENEKAN JUMLAH LEMAK TUBUH DAN GAS AMONIA EKSKRETA ITIK MELALUI MANAJEMEN PAKAN PROBIOTIK
}

\author{
RONI, N. G. K., E. PUSPANI, DAN I G. N. G. BIDURA \\ Fakultas Peternakan, Universitas Udayana \\ Jln. P.B. Sudirman, Denpasar-Bali \\ e-mail: gustironi_fapetunud@yahoo.com
}

\begin{abstract}
ABSTRAK
Penelitian ini bertujuan untuk mengkaji pengaruh suplementasi kultur Saccharomyces spp. dalam ransum sebagai upaya untuk menekan jumlah lemak tubuh dan gas ammonia ekskreta itik, dilaksanakan di Tabanan, Bali. Rancangan yang digunakan adalah rancangan acak lengkap (RAL) dengan empat perlakuan dan enam kali ulangan. Tiap ulangan menggunakan enam ekor itik bali jantan umur dua minggu dengan berat badan homogen. Ransum yang diberikan selama penelitian disusun dengan kandungan protein kasar 18\% dan energi termetabolis $2900 \mathrm{kkal} / \mathrm{kg}$ tanpa suplementasi kultur Saccharomyces spp. sebagai kontrol (A); suplementasi masing-masing: 0,10\%, 0,20\%, dan 0,30\% kultur Saccharomyces spp. dalam ransum kontrol, masing-masing sebagai perlakuan B, C, dan D. Ransum dan air minum selama penelitian diberikan secara ad libitum. Variabel yang diamati adalah konsumsi ransum, berat potong, lemak abdomen, dan kadar gas amonia ekskreta. Hasil penelitian menunjukkan bahwa suplementasi kultur Saccharomyces spp. dalam ransum basal pada level 0,20\% (C) dan 0,30\% (D) secara nyata $(\mathrm{P}<0,05)$ dapat meningkatkan berat potong itik dibandingkan dengan tanpa suplementasi (A). Akan tetapi, jumlah lemak abdomen, kadar kolesterol plasma, dan kadar gas amonia ekskreta itik nyata $(\mathrm{P}<0,05)$ lebih rendah daripada kontrol. Dapat disimpulkan bahwa suplementasi kultur Saccharomyces spp. yang diisolasi dari ragi tape dalam ransum basal pada level 0,20-0,30\% dapat meningkatkan bobot potong dan menurunkan jumlah lemak abdomen tubuh, serta kadar gas amonia dalam ekskreta itik Bali jantan umur 2-8 minggu.
\end{abstract}

Kata kunci: Saccharomyces spp., probiotik, lemak abdomen, amonia, itik

\section{PROBIOTICS FEEDING MANAGEMENTAS AN EFFORT FOR PRESSURING BODY FAT AND EXCRETE AMMONIA CONCENTRATION OF BALI DRAKE}

\begin{abstract}
This research was carried out to study the effect of probiotics supplementation in ration for pressuring body fat and excrete ammonia- $\mathrm{N}$ concentration of bali drake up to eight weeks of age. The design of experiment used a Completely Randomized Design (CRD) with four treatments and six replications with six birds in each replication. There were four diets evaluated as of: (A) ration without Saccharomyces spp. culture (as a probiotics sources) supplemented as a control, (B) ration with 0,10\% Saccharomyces spp. culture, (C) 0,20\% Saccharomyces spp. Culture and o,30\% Saccharomyces spp. culture supplemented, respectively. Diet and drinking water were provided ad libitum. Variables were observed in this experiment namely feed consumptions, final body weight, abdominalfat, and excrete ammonia-N concentration of drake. The results showed that supplemented both $0,20 \%$ and 0,30\% Saccharomyces spp. culture in basal diets were increased significantly different $(\mathrm{P}<0,05)$ final body weight than control diets (A). But, both of abdominal fat and excrete ammonia-N concentration of birds were decreased significantly different $(\mathrm{P}<0,05)$ than control. It was concluded that supplementation of $0,20-0,30 \%$ Saccharomyces spp. culture in basal diets were increased body weight, but decreasing abdominal-fat and excrete ammonia-N concentration of bali drake up to eight weeks of age.
\end{abstract}

Key words: Saccharomyces sppprobiotics, abdominal-fat, ammonia-N, drake.

\section{PENDAHULUAN}

Perhatian masyarakat terhadap lemak dan kolesterol menjadi semakin besar terutama setelah diketahui bahwa mengkonsumsi lemak/kolesterol yang berlebihan dapat mempengaruhi kesehatan. Tidak saja terhadap peningkatan penyakit jantung koroner, tetapi akhirakhir ini diinformasikan juga terhadap penyakit kanker, diabetes, dan tekanan darah tinggi (Santoso, 2000).

Akumulasi lemak yang tinggi pada perut dan viscera 
akan memperkecil keuntungan yang diperoleh pabrik pasca panen dan meningkatkan masalah pengolahan limbah, karena lemak abdomen bukan bagian dari karkas. Oleh karena itu, sangat bermanfaat apabila dapat menurunkan kolesterol dan lemak tubuh ayam melalui manajemen perbaikan ransum yang diberikan, yaitu dengan memanfaatkan bioteknologi probiotik. Hasil penelitian Mohan et al. (1996) menunjukkan bahwa suplementasi probiotik (L. acidophilus, L. casei, Bifidobacterium bifidum, Torulopsis, dan Aspergilus oryzae) nyata dapat meningkatkan pertumbuhan dan menurunkan serum kolesterol ayam

Disisi lain, ternyata masalah pencemaran amonia dan E. choli mendapat sorotan penting dalam dunia peternakan, karena semakin banyaknya peternakan yang intensif. Level amonia yang berlebihan dapat menurunkan produktivitas ternak ayam dan meningkatnya kepekaan terhadap serangan penyakit. Untuk mengatasi hal tersebut adalah dengan menerapkan bioteknologi probiotik melalui ransum yang diberikan (Anon., 1992).

Saccharomyces cerevisiae dapat berperan sebagai mikroba probiotik dan juga dapat meningkatkan kecernaan pakan berserat tinggi (Wallace dan Newbold, 1993), menjadi produk asam lemak terbang. Asam lemak terbang ini khususnya asam propionat, menurut Harianto (1996) dapat berperan untuk menghambat sintesis kolesterol di dalam hati, yaitu dengan jalan menekan aktivitas enzim 3-hidroxy-3-methyl glutaryl Co-A reduktase yang berperan dalam sintesa kolesterol di dalam hati.

Khamir Saccharomyces sp sebagai sumber probiotik dalam pakan bertujuan untuk meningkatkan jumlah bakteri asam laktat (BAL) yang akan mempengaruhi sejumlah proses pencernaan dan penyerapan lemak di dalam saluran pencernaan. Dalam saluran pencernaan, bakteri asam laktat mampu memanfaatkan energi yang berasal dari sumber karbohidrat untuk menurunkan $\mathrm{pH}$ saluran pencernaan menjadi 4,5 yang mengakibatkan suasana di dalam saluran pencernaan menjadi asam. Lingkungan asam menyebabkan aktivitas enzim lipase menjadi terbatas, sehingga pencernaan lemak berkurang dan selanjutnya pembentukkan lemak tubuh pun menjadi menurun (Piliang et al., l990)

Penggunaan probiotik dalam ransum dapat meningkatkan kandungan "lysine analoque S-2-aminoethylcysteine" dalam saluran pencernaan unggas (Sand dan Hankins, l996). Peningkatan kandungan asam amino lisin di dalam tubuh akan meningkatkan retensi energi sebagai protein dan dan menurunnya retensi energi sebagai lemak dalam tubuh (Sibbald dan Wolynetz, l986). Dilaporkan juga oleh Abdulrahim et al. (1996) bahwa penggunaan probiotik dalam ransum ternyata dapat menurunkan kandungan kolesterol telur.

Gas amonia di dalam kandang dapat berasal dari bakteri yang mati, kotoran, dan air seni, dan gas ini paling banyak mempengaruhi penampilan ayam (Arifien, l998). Dilaporkan juga, dalam jumlah 0,003\% dalam udara akan mengakibatkan $\mathrm{pH}$ darah naik, reabsorpsi oleh paru-paru, kemampuan oksidasi menurun, menekan pernafasan dan sirkulasi darah, merusak alat pernafasan dan mata.

Salah satu cara untuk menurunkan kadar gas amonia feses adalah dengan jalan menekan degradasi urea, yaitu dengan jalan memisahkan antara urine dan feses, atau dapat dilakukan dengan menggunakan urease inhibitor. Probiotik ternyata dilaporkan mampu menekan aktivitas enzim urease, serta dapat menurunkan jumlah asam urat dalam saluran pencernaan ayam, karena asam urat sudah dimanfaatkan menjadi protein mikrobial (Chiang dan Hsieh, 1995).

Beberapa hasil penelitian pendahuluan mengenai penggunaan ragi dalam ransum ternyata mampu meningkatkan penampilan, nilai guna pakan serat, dan menurunkan perlemakan tubuh unggas. Candraasih dan Bidura (2001) melaporkan bahwa penggunaan 0,50\% ragi pada ransum yang mengandung $15 \%$ cangkang coklat nyata dapat meningkatkan pertambahan berat badan itik. Demikian juga halnya dengan suplementasi ragi pada serbuk gergaji kayu dapat menurunkan jumlah lemak subkutan termasuk kulit karkas (Ariana dan Bidura, 2001). Abdulrahim et al. (1996) melaporkan bahwa penggunaan probiotik dalam ransum nyata dapat menurunkan kandungan kolesterol telur.

Dari uraian tersebut di atas, perlu kiranya dilakukan penelitian yang bertujuan untuk mengetahui kemampuan kultur khamir Saccharomyces spp (sebagai sumber probiotik) yang diisolasi dari ragi tape untuk menekan jumlah lemak tubuh dan kadar gas ammonia dalam ekskreta itik.

\section{MATERI DAN METODE}

\section{Tempat dan Lama Penelitian}

Penelitian lapangan dilaksanakan di kandang milik petani peternak di Banjar Bakisan, Desa Denbantas, Tabanan, Bali, sedangkan analisis laboratorium dilaksanakan di Laboratorium Teknologi Hasil Ternak, Fakultas Peternakan, Universitas Udayana, Denpasar, selama tiga bulan.

\section{Kandang dan Itik}

Kandang yang digunakan adalah kandang dengan sistem battery colony dari bilah bambu sebanyak 24 buah. Tiap petak kandang berukuran panjang 0,50 $\mathrm{m}$, lebar 0,40 m, dan tinggi o,40 m. Semua petak kandang terletak dalam sebuah bangunan kandang dengan atap genteng dan sudah dilengkapi dengan tempat pakan dan air minum. 
Itik yang digunakan adalah itik bali jantan umur dua minggu yang diperoleh dari petani peternak itik lokal di daerah Tabanan dengan berat badan homogen.

\section{Ransum dan air Minum}

Ransum yang digunakan dalam penelitian ini dihitung berdasarkan Tabel komposisi zat makanan menurut Scott et al. (1982), dengan menggunakan bahan seperti: jagung kuning, tepung ikan, bungkil kelapa, dedak padi, kulit gandum, kulit kacang kedelai, garam, dan premix. Semua perlakuan ransum disusun isokalori (ME: $2900 \mathrm{kcal} / \mathrm{kg}$ ) dan isoprotein (CP: 18\%). Air minum yang diberikan bersumber dari perusahan air minum setempat.

\section{Probiotik}

Sebagai sumber probiotik adalah kultur khamir Saccharomyces spp diisolasi dari ragi tape yang umumnya digunakan dalam pembuatan tape, merk "Na Kok Liong”, terdaftar nomor 26895 yang diperoleh dari pasar umum setempat.

\begin{tabular}{lcccc}
\multicolumn{5}{c}{ Tabel 1. Komposisi bahan pakan dalam ransum itik umur 2-8 minggu } \\
\hline \multirow{2}{*}{ Bahan Pakan (\%) } & \multicolumn{4}{c}{ Suplementasi Kultur Saccharomyces spp (\%) } \\
\cline { 2 - 5 } & 0,00 & 0,10 & 0,20 & 0,30 \\
\hline Jagung kuning & 56,50 & 56,50 & 56,50 & 56,55 \\
Pollard & 11,00 & 11,00 & 11,00 & 11,00 \\
Dedak padi & 9,00 & 8,85 & 8,75 & 8,70 \\
Bungkil kelapa & 3,30 & 3,30 & 3,30 & 3,30 \\
Kacang kedelai & 6,00 & 6,00 & 6,00 & 6,00 \\
Tepung ikan & 13,00 & 13,00 & 13,00 & 13,00 \\
Minyak kelapa & 0,70 & 0,75 & 0,75 & 0,75 \\
Mineral-mix & 0,50 & 0,50 & 0,50 & 0,50 \\
Kultur Saccharomyces spp & 0,00 & 0,00 & 0,00 & 0,00 \\
Total & 100 & 100 & 100 & 100 \\
\hline
\end{tabular}

Tabel 2. Komposisi zat makanan dalam ransum itik umur 2-8 minggu ${ }^{1)}$

\begin{tabular}{lcccccc}
\hline \multirow{2}{*}{ Zat Makanan } & & \multicolumn{5}{c}{ Perlakuan } \\
\cline { 3 - 7 } \multicolumn{2}{c}{} & $\mathrm{A}$ & $\mathrm{B}$ & $\mathrm{C}$ & $\mathrm{D}$ & \\
\hline Energi termetabolis & $(\mathrm{kkal} / \mathrm{kg})$ & 2901 & 2903 & 2902 & 2903 & 2900 \\
Protein kasar & $(\%)$ & 18,01 & 18,08 & 18,07 & 18,07 & 18.00 \\
Serat kasar & $(\%)$ & 4,24 & 4,22 & 4,21 & 4,20 & $5-7$ \\
Lemak kasar & $(\%)$ & 6,82 & 6,85 & 6,84 & 6,84 & $5-10$ \\
Ca & $(\%)$ & 1,06 & 1,06 & 1,06 & 1,06 & $0.8-1.2$ \\
P-tersedia & $(\%)$ & 0,64 & 0,64 & 0,64 & 0,64 & 0.40 \\
Arginin & $(\%)$ & 1,27 & 1,27 & 1,27 & 1,27 & 1.00 \\
Lysin & $(\%)$ & 1,25 & 1,25 & 1,25 & 1,25 & 0.82 \\
Metionin+sistein & $(\%)$ & 0,75 & 0,74 & 0,74 & 0,74 & 0.60 \\
\hline
\end{tabular}

Keterangan :

1. Berdasarkan perhitungan Scott et al. (1982)

2. Berdasarkan standar Farrell (1995)

\section{Pemberian Ransum dan Air Minum}

Ransum perlakuan dan air minum diberikan ad libitum sepanjang periode penelitian. Penambahan ransum dilakukan 2-3 kali sehari dan diusahakan tempat ransum terisi $3 / 4$ bagian, untuk mencegah agar ransum tidak tercecer.

\section{Rancangan Percobaan}

Rancangan yang dipergunakan dalam penelitian ini adalah rancangan acak lengkap (RAL) dengan empat macam perlakuan dan enam kali ulangan. Tiap ulangan (unitpercobaan)menggunakan enam ekoritikbalijantan umur dua minggu dengan berat badan homogen. Ke empat perlakuan yang dicobakan adalah: ransum basal tanpa penambahan kultur Saccharomyces spp sebagai kontrol (A); ransum dengan penambahan $0,10 \%$ kultur Saccharomyces spp (B); ransum dengan penambahan 0,20\% Saccharomyces spp (C); dan ransum dengan penambahan 0,30\% kultur Saccharomyces spp (D)

\section{Variabel yang Diamati}

Variabel yang diamati dalam penelitian ini adalah:

- Konsumsi ransum: konsumsi ransum diukur setiap minggu sekali, yaitu selisih antara jumlah ransum yang diberikan dengan sisa ransum.

- Berat potong itik: merupakan berat badan itik ada akhir penelitian yang telah mengalami puasa pakan selama 12 jam.

- Perlemakan tubuh itik, yaitu pemisahan lemak yang ada ada disekitar saluran pencernaan (mecenteric-fat), lemak bantalan (pad-fat), lemak empedal (ventriculusfat), dan gabungan ketiga komponen lemak tersebut adalah lemak abdomen (abdominal-fat).

- Kadar $\mathrm{N}_{-} \mathrm{NH}_{3}$ ekskreta: penentuan kadar $\mathrm{N}^{-\mathrm{NH}_{3}}$ dengan menggunakan difusi Conway (Saransi et al., 2010) sebagai berikut: $1 \mathrm{ml}$ sampel supernatant disebelah kiri sekatan cawan Conway, $1 \mathrm{ml}$ larutan $\mathrm{Na}_{2} \mathrm{CO}_{3}$ jenuh pada sekat sebelah kanan, $1 \mathrm{ml} \mathrm{H}_{3} \mathrm{BO}_{3}$ $2 \%$ yang berindikator BCG + MR pada cawan tengah, kemudian tutup cawan conway bervaselin dengan rapat, goyang dengan perlahan sampai supernatant dengan $\mathrm{Na}_{2} \mathrm{CO}_{3}$ bercampur sempurna, kemudian biarkan 24 jam dalam suhu kamar, selanjutnya lakukan titrasi dengan menggunakan $\mathrm{H}_{2} \mathrm{SO}_{4} \mathrm{O}, \mathrm{OO} 5$ $\mathrm{N}$ sampai titik akhir titrasi. Kadar $\mathrm{N}-\mathrm{NH}_{3}$ dapat dihitung sebagai berikut ini: $m \mathrm{MN}-\mathrm{NH}_{3}=($ Volume titrasi $x \mathrm{NH}_{2} \mathrm{SO}_{4} \times 1.000$ )

\section{Analisis Statistika}

Data yang diperoleh di analisis dengan sidik ragam dan apabila terdapat perbedaan yang nyata $(\mathrm{P}<0,05) \mathrm{di}$ antara perlakuan, maka dilanjutkan dengan uji jarak berganda dari Duncan (Steel and Torrie, l993).

\section{HASIL DAN PEMBAHASAN}

\section{Berat Potong}

Hasil penelitian menunjukkan bahwa berat potong itik umur delapan minggu yang diberi ransum basal sebagai kontrol (A) adalah 895,72 g/ekor (Tabel 3). Penambahan kultur khamir Saccharomyces spp yang 
diisolasi dari ragi tape dalam ransum basal masingmasing pada level: 0,1\% (B); 0,20\% (C); dan 0,30\% (D), menghasilkan berat potong yang lebih tinggi secara berturutan adalah: $1,41 \%$ tidak nyata $(\mathrm{P}>0,05) ; 27,05 \%$; dan $28,70 \%$ nyata $(\mathrm{P}<0,05)$ lebih tinggi daripada kontrol (A). Hal ini terjadi karena khamir Saccharomyces spp dalam saluran pencernaan mampu meningkatkan kecernaan pakan. Nampaknya, peran kultur khamir Saccharomyces spp. sebagai agensia probiotik dalam saluran pencernaan itik efektif pada level o,20-0,30\% dalam ransum. Piao et al. (1999) menyatakan bahwa suplementasi probiotik dalam ransum nyata dapat meningkatkan pertambahan berat badan, pemanfaatan zat makanan, serta kecernaan nitrogen dan phosphor. Dilaporkan juga oleh Stanley et al. (l993), ayam broiler yang diberi Saccharomyces cerevisiae 0,10\% nyata meningkatkan pertambahan berat badan dan efisiensi penggunaan ransum. Disamping itu, ragi/khamir dalam ransum dapat meningkatkan sekresi mucin. Mucin merupakan zat yang sangat penting artinya bagi habitat dan sumber zat makanan bagi mikrobia yang menguntungkan dalam saluran pencernaan ayam (Savage, 1991). Menurut Chesson (1994), respons pemberian probiotik pada ternak akan berbeda pengaruhnya, dan hal tersebut sangat dipengaruhi oleh strain bakteri yang digunakan sebagai probiotik, dosis atau level pemberiannya, komposisi ransum, sistem pemberian pakan, bentuk ransum, dan interaksi dengan feed additive lainnya.

\section{Konsumsi Ransum}

Rataan jumlah ransum yang dikonsumsi oleh itik kontrol selama 4 minggu pengamatan adalah 4985,15 g/ekor/4 minggu (Tabel 3). Penambahan kultur khamir Saccharomyces spp dalam ransum ternyata tidak berpengaruh nyata $(\mathrm{P}>0,05)$ terhadap konsumsi ransum. Pemberian pakan yang mengandung probiotik dapat memacu perbaikan metabolisme pakan pada proses pencernaan (Nurhayati, 2008). Dilaporkan juga oleh Yi et al. (1996), bahwa suplementasi mikroba ke dalam ransum nyata dapat meningkatkan retensi nitrogen pada broiler, proses fermentasi akan memecah protein dan karbohidrat menjadi asam amino, nitrogen, dan karbon terlarut yang diperlukan untuk sintesis protein tubuh (Rahayu et al., 1989). Tang et al. (2007) menyatakan bahwa peningkatan konsumsi protein dan asam amino lysin pada ayam broiler menyebabkan peningkatan jumlah daging dada dibandingkan dengan konsumsi protein dan lysin yang lebih rendah. Utama (2011) menyatakan bahwa khamir S.cerevisiae merupakan khamir yang mampu memproduksi enzim amilase dan selulolase, sehingga dapat meningkatkan daya cerna protein dan selulosa maupun hemiselulosa, karena sudah dirombak dalam bentuk monosakarida sederhana. Pencernaan selulosa sangat tergantung pada bakteri yang terdapat disepanjang saluran pencernaan ternak. Bakteri selulolitik mampu memproduksi enzim endo 1,4 b-glukonase, ekso 1,4 b-glukonase, dan b-glukosidase yang dapat mendegradasi komponen serat kasar menjadi karbohidrat terlarut.

Tabel 3. Pengaruh penambahan kultur khamir Saccharomyces spp sebagai sumber probiotik yang diisolasi dari ragi tape dalam ransum terhadap bobot potong, konsumsi ransum, lemak bantalan, lemak abdomen, dan kadar N-NH3 ekskreta itik umur 8 minggu

\begin{tabular}{|c|c|c|c|c|c|}
\hline \multirow{2}{*}{ Variabel yang Diamati } & \multicolumn{4}{|c|}{ Perlakuan $^{1)}$} & \multirow{2}{*}{ SEM $^{2)}$} \\
\hline & $A$ & B & $\mathrm{C}$ & D & \\
\hline Berat potong (g/ekor) & $895,72^{\mathrm{b} 3)}$ & $908,38^{b}$ & $1138,02^{a}$ & $1152,75^{a}$ & 34,052 \\
\hline $\begin{array}{l}\text { Kons. Ransum } \\
\text { (g/ekor/4 minggu) }\end{array}$ & $4985,15^{a}$ & $5023,71^{a}$ & $5064,92^{a}$ & $5078,05^{a}$ & 67,927 \\
\hline \multicolumn{6}{|c|}{ Distribusi lemak tubuh (\% berat badan) } \\
\hline Pad-fat & $0,48 a$ & $0,46 a$ & $0,39 b$ & $0,38 b$ & 0,014 \\
\hline Abdominal-fat & $1,05 a$ & $1,07 a$ & $0,91 b$ & $0,87 b$ & 0,035 \\
\hline $\begin{array}{l}\text { Amonia/N-NH } \\
\text { (m.Mol/ltr) }\end{array}$ & $68,93^{a}$ & $67,06^{a}$ & $56,97^{b}$ & $54.14^{b}$ & 2,703 \\
\hline
\end{tabular}

Keterangan :

1. Ransum basal tanpa suplementasi kultur Saccharomyces spp. sebagai kontrol (A); dengan suplementasi 0,10\% kultur Saccharomyces spp. (B); dengan suplementasi $0,20 \%$ kultur Saccharomyces spp. (C); dan ransum basal dengan suplementasi $0,30 \%$ kultur Saccharomyces spp. (D);

2. SEM :"Standard Error of Treatment Means"

3. Nilai dengan huruf yang sama pada baris yang sama menunjukan perbedaan yang tidak nyata $(\mathrm{P}>0.05)$

\section{Lemak Bantalan dan Lemak Abdomen}

Hasil penelitian menunjukkan bahwa rataan jumlah lemak bantalan ( $p a d-f a t$ ) pada tubuh itik kontrol adalah $0,48 \%$ berat potong (Tabel 3). Pada penambahan 0,10\% kultur khamir Saccharomyces spp dalam ransum basal (B), rataan jumlah lemak bantalannya tidak menunjukkan adanya perbedaan yang nyata ( $\mathrm{P}>0,05)$ dengan kontrol. Penambahan kultur khamir Saccharomyces spp dalam ransum basal pada tingkat 0,20\% (C) dan 0,30\% (D), mampu menurunkan lemak bantalan (pad-fat) secara nyata $(\mathrm{P}<0,05)$ masingmasing $18,75 \%$ dan 20,83\% dibandingkan dengan kontrol.

Rataan jumlah lemak abdomen (abdominal-fat) pada tubuh itik kontrol adalah 1,05\% berat potong (Tabel 3). Penambahan 0,10\% kultur khamir Saccharomyces spp dalam ransum basal (B), menghasilkan rataan jumlah lemak abdomen yang berbeda tidak nyata ( $P>0,05)$ dengan kontrol. Pada penambahan kultur khamir Saccharomyces spp dalam ransum basal pada tingkat $0,20 \%$ (C) dan $0,30 \%$ (D), rataan jumlah lemak abdomennya masing-masing $13,33 \%$ dan $17,14 \%$ nyata $(\mathrm{P}<0,05)$ lebih rendah daripada kontrol.

Pemberian pakan yang diberi tambahan kultur Saccharomyces spp., nyata menurunkan jumlah lemak bantalan (pad-fat) dan lemak abdomen (abdominal-fat) itik. Lemak makanan yang dimakan dalam usus dicerna oleh enzim pankreas dan diemulsikan oleh garam 
empedu menjadi micelles atau kilomikron. Micelles inilah yang diserap oleh tubuh sebagai sumber tenaga dan bahan dasar pembentuk kolesterol, selanjutnya didepositkan pada bagian organ tubuh. Piliang et al. (l990) melaporkan bahwa khamir Saccharomyces $s p$ sebagai sumber probiotik dalam pakan dapat meningkatkan jumlah bakteri asam laktat (BAL) yang akan mempengaruhi sejumlah proses pencernaan dan penyerapan lemak di dalam saluran pencernaan ternak unggas. Bakteri asam laktat dalam saluran pencernaan ternak unggas mampu memanfaatkan energi yang berasal dari sumber karbohidrat untuk menurunkan $\mathrm{pH}$ saluran pencernaan menjadi 4,5 yang mengakibatkan suasana di dalam saluran pencernaan menjadi asam. Lingkungan asam menyebabkan aktivitas enzim lipase menjadi terbatas, sehingga pencernaan lemakberkurang dan selanjutnya pembentukkan lemak tubuhpun menjadi menurun. Hasil penelitian Nurhayati (2008) menunjukkan bahwa penggunaan campuran pakan terfermentasi oleh A.niger pada level $10-30 \%$ secara nyata menurunkan bobot lemak abdominal dan tidak berpengaruh nyata terhadap bobot daging dada ayam.

\section{Amonia/N-NH ${ }_{3}$ Ekskreta}

Rataan kadar ammonia $\left(\mathrm{N}-\mathrm{NH}_{3}\right)$ dalam ekskreta itik kontrol adalah 68,93 m.Mol/ltr (Tabel 3) dan tidak menunjukkan adanya perbedaan yang nyata $(\mathrm{P}>0,05)$ dengan kadar ammonia dalam ekskreta itik yang diberi ransum B. Panambahan masing-masing: 0,20\% (C) dan 0,30\% (D) kultur Saccharomyces spp dalam ransum basal, secara nyata $(\mathrm{P}<0,05)$ dapat menurunkan kadar ammonia dalam ekskreta itik masing-masing: 17,35 dan 21,46\% dibandingkan dengan kontrol.

Penambahan 0,20-0,30\% kultur khamir Saccharomyces spp sebagai sumber probiotik dalam ransum nyata menurunkan kandungan $\mathrm{N}-\mathrm{NH}_{3}$ ekskreta itik. Kadar gas ammonia sebesar 0,003\% di udara, dapat mengakibatkan $\mathrm{pH}$ darah naik, reabsorpsi oleh paru-paru, kemampuan oksidasi menurun, menekan pernafasan, dan sirkulasi darah, merusak alat pernafasan dan mata (Arifien, 1998). Salah satu cara untuk menurunkan kadar gas amonia feses adalah dengan jalan menekan degradasi urea, yaitu dengan jalan memisahkan antara urine dan feses, atau dapat dilakukan dengan menggunakan urease inhibitor. Probiotik ternyata dilaporkan mampu menekan aktivitas enzim urease dan dapat menurunkan jumlah asam urat dalam saluran pencernaan ayam, karena asam urat sudah dimanfaatkan menjadi protein mikrobial (Chiang dan Hsieh, 1995).

Penurunan kadar $\mathrm{N}^{-\mathrm{NH}_{3}}$ pada ekskreta itik yang diberikan ransum mengandung probiotik tersebut, menurut Yeo dan Kim (1997) disebabkan karena probiotik dalam ransum (Lactobacillus cassei) dapat menekan aktivitas enzim urease dalam usus kecil, sehingga kadar gas organik dalam ekskreta menurun. Menurut Chiang dan Hsieh (1995), penurunan kandungan gas organik ekskreta tersebut karena probiotik dapat meningkatkan kecernaan protein pakan dan dapat menurunkan jumlah asam urat. Asam urat tersebut dimanfaatkan menjadi protein organik sehingga keberadaannya di dalam ekskreta menurun. Piao et al. (1999) menyatakan bahwa penggunaan Saccharomyces serevisiae 0,10\% dalam ransum nyata dapat menurunkan jumlah nitrogen dan fosfor yang disekresikan dalam feses ayam. Dilaporkan juga oleh Han et al. (1999), bahwa suplementasi Aspergillus oryzae dan S.cerevisiae dalam ransum basal secara signifikan dapat meningkatkan jumlah bakteri asam laktat (BAL) serta menurunkan jumlah bakteri E.choli dan bakteri aerobik dalam ekskreta. Bakteri asam laktat sangat survive dalam saluran pencernaan ternak unggas, dan hal inilah yang dapat menyebabkan jumlah bakteri E.choli dan konsentrasi $\mathrm{N}-\mathrm{NH}_{3}$ dalam ekskreta menurun. Chen et al. (2002) melaporkan bahwa suplementasi probiotik kompleks ke dalam ransum secara nyata meningkatkan pertambahan berat badan dan menurunkan kadar $\mathrm{N}-\mathrm{NH}_{3}$ feses.

Amonia dalam sekum dapat mengganggu pertumbuhan ternak dan keberadaan mikroba probiotik dapat memanfaatkan ammonia tersebut untuk sintesis asam amino non-esensial (Karasawa dan Maeda, 1994). Santoso et al. (2001) melaporkan bahwa penggunaan produk pakan terfermentasi (Bacillus subtili) dalam ransum ayam, secara nyata dapat menurunkan pelepasan gas ammonia, sedangkan sekresi total $\mathrm{N}$, $\mathrm{N}$-urat, dan $\mathrm{N}$-amonia dalam feses tidak menunjukkan adanya perbedaan yang nyata.

\section{SIMPULAN}

Dari hasil penelitian ini dapat disimpulkan bahwa penambahan 0,20-0,30\% kultur khamir Saccharomyces spp yang diisolasi dari ragi tape nyata dapat meningkatkan bobot potong serta menurunkan jumlah lemak abdomen tubuh dan kadar $\mathrm{N}^{-\mathrm{NH}_{3}}$ dalam ekskreta itik Bali jantan umur 2-8 minggu.

\section{UCAPAN TERIMAKASIH}

Pada kesempatan ini penulis mengucapkan terimakasih kepada Rektor Universitas Udayana atas dana yang diberikan melalui dana Penelitian Dosen Muda, sehingga penelitian dan penyusunan tulisan ilmiah ini dapat terlaksana. Ucapan terimakasih penulis sampaikan pula kepada Bapak Putu Tegik (Alm.) atas bantuannya dalam analisis sampel. 


\section{DAFTAR PUSTAKA}

Abdulrahim, S.M., M.S.Y. Haddadin, E.A.R. Haslamoun and R.K. Robinson. 1996. The influence of Lactobacillus acidhophilus and bacitracin on layer performance of chickens and cholesterol content of plasma and egg yolk. British Poult. Sci. 37: 341-346.

Anonymous. 1992. Wawasan lingkungan dan bioteknologi. Infovet no. 004, Agustus - Oktober l992, Hal: 24- 26

Ariana, I. N. T., dan I G.N.G. Bidura. 2001. Bobot dan komposisi fisik karkas ayam broiler yang diberi ransum dengan penambahan serbuk gergaji kayu, ragi tape dan kombinasinya. Majalah Ilmiah Peternakan 4 (1): 21-26

Arifien, M. 1998. Mengurangi gas yang merugikan di kandang. Poultry Indonesia Edisi Desember 1998, No: 224, Hal: 32-33

Candraasih, N.N.K., dan I G.N.G. Bidura. 2001. Pengaruh penggunaan cangkang kakao yang disuplementasi ragi tape dalam ransum terhadap penampilan itik bali. Majalah Ilmiah Peternakan 4 (3): 67-72.

Chen, Y. H., H. K. Hsu, and J. C. Hsu. 2002. Studies on the fine structure of caeca in domestic geese. AJAS 15 (7): 1018-1021

Chesson, A. 1994. Probiotics and Other Intestinal Mediators. In: (Ed. D.J.A. Cole, J. Wiseman, and M.A. Varley) Principles of Pig. Science. Loughborgough, UK: Nottingham University Press. Pp. 197-214.

Chiang, S.H., and W.M. Hsieh. 1995. Effect of direct feed microorganisms on broiler growth performance and litter ammonia level. AJAS 8: 159-162

Farrel, D.J. 1995. Table Egg Laying Ducks: Nutritional requirement and husbandry systems in asia. Poult and Avian Biol. Rev. 6 (1): 55-69.

Han, S.W., K.W. Lee, B.D. Lee, and C.G. Sung. 1999. Effect of feeding Aspergillus oryzae culture on fecal microflora, egg qualities, and nutrient metabolizabilities in laying hens. AJAS 12 (3): 417-421

Karasawa, Y. and M. Maeda. 1994. Role of caecal in the nitrogen nutrition of the chicken fed on a moderate protein diet or a low protein diet plus urea. Br. J. Nutr. 35: 383-391

Mohan, B., R. Kadirvel, M. Bhaskaran, and A. Natarajan. 1995. Effect of probiotic suplementation on serum and yolk kolesterol and egg shell thicness in layers. British Poultry Sci. 36: 799-803

Nurhayati. 2008. Pengaruh tingkat penggunaan campuran bungkil inti sawit dan onggok yang difermentasi dengan Aspergillus Niger dalam pakan terhadap bobot dan bagian-bagian karkas broiler. Animal Production Vol. 10 (1): $55-59$

Piao, X. S., I. K. Han, J. H. Kim, W. T. Cho, Y. H. Kim, and C. Liang. 1999. Effects of kemzyme, phytase, and yeast supplementation on the growth performance and pullution reduction of broiler chicks. Asian-Aust. J. Anim. Sci. 12 (1): 36-41

Piliang, W.G. 1990. Strategi Penyediaan Pakan Ternak Berkelanjutan Melalui Pemanfaatan Energi Alternatif. Orasi Ilmiah Guru Besar Tetap Ilmu Nutrisi, Fapet IPB, Bogor.

Rahayu, K., Kuswanto, dan S. Sudarmadji. 1989. Mikrobio- logi Pangan. Pusat Antar Universitas Pangan dan Gizi. Yogyakarta: Universitas Gadjah Mada.

Sand, D.C. and L. Hankin. 1996. Fortification of foods by fermentation with lysine-exreting mutants of Lactobacilli. J. Agric. Food Chem. 24 : 1104-1106

Santoso, U. 2000. Pengaruh pemberian ekstrak daun keji beling (Strobilanthes crispus BL.) terhadap performans dan akumulasi lemak pada broiler. Jurnal Peternakan dan Lingkungan 6 (2): 10-14

Santoso, U., K. Tanaka, S. Ohtami, and M. Sakaida. 2001. Effect of fermented product from Bacillus subtilis on feed convertion efficiency, lipid accumulation and ammonia production in broiler chicks. Asian-Aust. J. Anim. Sci. 14 (3): 333-337

Saransi, A.U., T.I. Putri, I.M. Mudita, D.P.M.A. Candrawati dan I.G.N.G. Bidura. 2010. Buku Penuntun Praktikum. Laboratorium Nutrisi, Fakultas Peternakan, Universitas Udayana, Denpasar

Savage, D.C. 1991. Modes of Action. Pages11-81 In: Direct-Fed Microbials In Animal Production. A Review of literature. West Des Moines, IA.: National Feed Ingradients Association

Sibbald, I.R., and M.S. Wolynetz. 1986. Effects of dietary lysine and feed intake on energy utilization and tissue synthesis by broiler chicks. Poult. Sci. 65: 98-105

Scott, M.L., M.C. Neisheim and R.J. Young. 1982. Nutrition of The Chickens. 2nd Ed. Publishing by: M.L. Scott and Assoc. Ithaca, New York.

Stanley, V.G., R. Ojo, S. Woldesnbet, D. Hutchinson and L. F. Kubena. 1993. The use of Saccharomyces Sereviseae to supress the effects of aflatoxicosis in broiler chicks. Poult. Sci. 72: 1867-1872.

Steel, R.G.D., and J.H.Torrie. 1993. Prinsip dan Prosedur Statistik. PT. Gramedia Pustaka Utama, Jakarta.

Tang. M.Y., Q.G. Ma, X.D. Chen, and C. Ji. 2007. Effects of dietary metabolizable energy and lysine on carcass characteristics and meat quality in arbor acres broiler . AJAS vol. 20 (12):1865-1873

Utama, C.S.N. 2011. Potensi probiotik bekatul. Poultry Indonesia. Vol. VI, September: 78-80

Wallace, R.J. and W. Newbold. 1993. Rumen Fermentation and Its Manipulation : The Development of Yeast Culture as Feed Additive. p : 173-192, In. T.P. Lyons Ed. Biotechnology in The Feed Industry Vol. IX. Altech Technical Publ. Nicholsville, KY.

Yeo, J. And K. Kim. 1997. Effect of feeding diets containing antibiotics, A probiotic or yucca extract on growth and intestinal urease activity in broiler chicks. Poult. Sci. 76: $381-385$

Yi, Z., E. T. Kornegay and D.M. Denbow. 1996. Effect of microbial phytase on nitrogen and amino acid digestibility and nitrogen retention of turkey poults fed corn-soybean meal diets. Poultry Sci. 75: 979-990 